\title{
Analisis Keaktifan Mahasiswa dalam Proses Pembelajaran Statistika Multivariat
}

\author{
Taufik Irsyad ${ }^{1}$, Endang Wuryandini ${ }^{2}$, Mahmud Yunus*3, Dwi Prastiyo Hadi ${ }^{4}$ \\ Universitas PGRI Semarang \\ Semarang, Indonesia
}

Riwayat Artikel

Tanggal

diajukan:

8 Juni 2020

Tanggal

diterima :

13 Juni 2020

Tanggal

dipublikasikan:

29 Juni 2020

Pengutipan:

Irsyad, T.,

Wuryandini, E.

Yunus, M. \&

Hadi, D. P.

(2020). Analisis

Keaktifan

Mahasiswa

dalam Proses

Pembelajaran

Statistika

Multivariat.

Jurnal

Pendidikan

Ekonomi

Undiksha, 12

(1), 89-96

\author{
e-mail: foster irsyad@yahoo.com¹, dyne64@yahoo.com², \\ mahmud_yunus@upgris.ac.id ${ }^{* 3}$,dwiikip58@gmail.com ${ }^{4}$
}

\begin{abstract}
Abstrak
Penelitian ini dilatarbelakangi oleh kondisi mahasiswa dalam proses pembelajaran mata kuliah statistik multivariat. Pada materi praktik penginputan data, output data, dan intepretasi data. Mahasiswa cenderung hanya mengikuti perkuliahan dan kurang aktif dalam mengajukan pertanyaan. Mahasiswa kurang aktif mencari materi tambahan diluar materi yang diajarkan oleh dosen. Metode penelitian menggunakan pendekatan kualitatif jenis studi kasus. Objek penelitian terdiri dari 23 mahasiswa yang mengikuti mata kuliah multivariat, Ketua Program Studi dan seorang dosen Pendidikan Ekonomi. Teknik pengumpulan data yang digunakan adalah observasi, wawancara, dan dokumentasi. Hasil penelitian ini adalah pembelajaran mata kuliah statistik multivariat dilakukan dengan baik. Proses kegiatan belajar mengajar memprioritaskan keaktifan mahasiswa sebagaimana dibuktikan dengan praktik yang dilakukan disetiap perkuliahan. Penyampaian materi dilakukan dengan menggunakan Bahasa Inggris. Keaktifan mahasiswa masih kurang karena mahasiswa kurang aktif bertanya. Motivasi mahasiswa cenderung rendah dalam mencari informasi tentang materi perkuliahan yang telah diajarkan atau akan diajarkan. Simpulan dari penelitian ini adalah bahwa disiplin, komitmen dan dorongan dari dalam mahasiswa adalah penting. Motivasi pribadi lebih memengaruhi keaktifan. implikasi peneltian ini sebagai sumbangsih kepada dosen agar dapat meningkatkan dorongan dari dalam diri mahasiswa agar dapat meningkatkan keaktifan dalam proses pembelajaran.
\end{abstract}

Kata kunci: keaktifan; belajar; motivasi; praktik

\begin{abstract}
This research is motivated by the condition of students in the learning process of multivariate statistics courses. In the matter of data input practice, data output, and data interpretation. Students tend to only follow lectures and are less active in asking questions. Students are less active in looking for additional material beyond the material taught by the lecturer. The research method uses a qualitative case study type approach. The research object consisted of 23 students who took multivariate courses, the Chair of the Study Program and a lecturer in Economic Education. Data collection techniques used were observation, interviews, and documentation. The results of this study are multivariate statistical learning courses performed well. The process of teaching and learning activities prioritize student activity as evidenced by the practice carried out in each lecture. The Submission of material is done using English. Student activeness is still lacking because students are less active in asking questions. Student motivation tends to be low in finding information about lecture material that has been taught or will be taught. The conclusion of this study is that discipline, commitment, and encouragement from within students are important. Personal motivation affects more activeness. This research has implications as a contribution to lecturers in order to be able to increase encouragement from within students in order to increase activity in the learning process.
\end{abstract}

Keywords: liveliness; learning; motivatio; practice 


\section{PENDAHULUAN}

Mahasiswa merupakan seorang yang telah dianggap lebih dewasa dari pada siswa, sehingga kegiatan belajar mengajarnya berbeda dengan siswa. Proses pembelajaran merupakan salah satu bagian yang penting dalam pendidikan (Widoyoko, 2009). Proses pembelajaran dapat menentukan hasil dari apa yang sudah didapatkan (Shadiq, 2009). Jika proses pembelajaran berjalan dengan baik maka diharapkan tujuan pembelajaran dapat tercapai (Pane \& Darwis Dasopang, 2017).

Pembelajaran yang efektif dan efisien dapat diciptakan apabila semua komponen pembelajaran dapat berjalan dengan sebagaimana mestinya (Tatang Hidayat, 2019). Menurut (Hernawan, A. H., Permasih, H., \& Dewi, 2012), komponenkomponen pembelajaran terdiri dari tujuan pembelajaran, materi pembelajar, metode pembelajaran, dan evaluasi. Keempat komponen ini saling mempengaruhi. Apabila salah satu komponen tidak sesuai maka akan mempengaruhi proses pembelajaran yang ada, karena akan berdampak kepada komponen-komponen yang lainnya (Dolong, 2016).

$$
\text { Asrori (2016) menjelaskan }
$$

komponen pembelajaran adalah runtutan proses yang saling berhubungan dan berkaitan antar kompenen yang dilakukan oleh pendidik dengan peserta didik untuk mencapai tujuan. Dolong (2016) menjelaskan kegiatan pengajaran akan berjalan dengan baik, efisien, dan efektif karena adanya hubungan yang positif anatara komponen pembelajaran. Ketepatan cara berinteraksi antara pendidik dengan peserta didik bisa mempengaruhi semua yang ada dalam proses pembelajaran (Akinoğlu \& Tandoğan, 2007). Terciptanya lingkungan yang kondusif akan menghasilkan pembelajaran yang terlaksana secara efektif.

Keberhasilan

pembelajaran dipengaruhi oleh banyak hal, diantaranya oleh dosen dan mahasiswa itu sendiri. Menurut Nurseto (2012), pembelajaran efektif merupakan pembelajaran yang berjalan dengan lancar dan dapat mengoptimalkan hasil belajar. Jika mahasiswa dan dosen ikut berkontribusi aktif dalam pembelajaran maka pembelajaran tersebut akan berjalan dengan efektif. Ketika mahasiswa aktif di dalam proses pembelajaran maka presentase keberhasilan pembelajaran tersebut akan lebih meningkat (Sani, 2013).

Di era yang modern saat ini, Larasati, D., Sumastuti, E., Hadi, D., \& Yunus (2020) mengungkapkan bahwa pemanfaatan teknologi dalam proses pendidikan perlu dimaksimalkan. Penggunaan teknologi dalam bidang pendidikan dapat memudahkan untuk mendapatkan informasi yang ingin didapatkan (Riwayadi, 2013). Kemudahan untuk mendapatkan informasi ini dapat mempengaruhi keberhasilan pembelajaran di bidang pendidikan (Gafar, 2008). Perkembangan teknologi yang semakin modern mempermudah mahasiswa untuk memperoleh informasi dengan cepat dan tepat (Daeng, Mewengkang, \& Kalesaran, 2017).

Kristiyanti (2010) menyatakan setiap institusi pendidikan semestinya memanfaatkan teknologi pembelajar untuk mencapai tingkat pembelajaran yang efektif. Oleh sebab itu sudah saatnya lembaga pendidikan mengembangkan pembelajaran dengan memanfaatkan perkembangan teknologi dalam kegiatan pembelajaran. Pemanfaatan teknologi informasi ini baik untuk pendidik ataupun untuk peserta didik, agar dapat dengan mudah mencari informasi dan bahan ajar yang ada (Mumtaz, 2000).

Kegiatan pembelajaran di perguruan tinggi mayoritas masih menggunakan strategi pembelajaran ceramah dimana dosen menyampaikan informasi yang ada sesuai dengan perancanaan awal (Annisa, 2016). Strategi pembelajaran ceramah yang dilakukan oleh dosen dengan menyampaikan materi kepada mahasiswa (Nudji DA, 2014). Seharusnya kegiatan pembelajaran dapat menggunakan strategi pembelajaran yang bervariasi (Ngadiyono, 2009). Dosen dapat memilih strategi pembelajaran yang dapat meningkatkan motivasi mahasiswa untuk aktif dalam proses pembelajaran(Fadllan, 2010). 
Keaktifan belajar dipengaruhi oleh faktor internal dan faktor eksternal (Yunus, 2013). Faktor internal merupakan faktor yang bersumber dari dalam diri mahasiswa sendiri. Sedangkan faktor eksternal merupakan faktor yang bersumber dari luar diri mahasiswa. Kesiapan dibutuhkan karena saat proses pembelajaran, mahasiswa dituntut untuk siap, dengan kesiapan tersebut mahasiswa akan mudah untuk mengikuti jalannya proses pembelajaran. Mulyani (2013) menyatakan kesiapan belajar yang baik dapat membuat mahasiswa bisa mengikuti proses pembelajaran dengan baik dan aktif.

Pujiningsih \& Mustikawati (2004) berpendapat, keaktifan mahasiswa untuk menyampaikan suatu pendapat atau bertanya mengenai materi perkuliahan masih sangat rendah meskipun mereka sudah diberi insentif poin apabila mereka aktif. Hal tersebut terjadi dikarenakan dari faktor internal dan eksternal di mahasiswa itu sendiri. Kurang siapnya mahasiswa untuk mengikuti pembelajaran dapat memberi dampak pada proses pembelajaran. Mahasiswa yang enggan mencari informasi mengenai materi yang akan dibahas dipertemuan berikutnya, dapat menghambat proses pembelajaran.

Berdasar permasalah yang telah dibawas, maka peneliti tertarik untuk menganalisis mengenai keaktifan mahasiswa dalam proses pembelajaran, mahasiswa pada saat pembelajaran cenderung hanya mengikuti alur yang diberikan dosen sehingga ini menjadikan suatu persoalan yang harus bisa ditangani.

Tujuan penelitian ini adalah 1) untuk mengetahui proses pembelajaran mata kuliah Statistika Multivariat 2) untuk menganalisis bagaimana keaktifan mahasiswa dalam proses pembelajaran mata kuliah Statistika Multivariat.

\section{METODE}

Penelitian ini menggunakan pendekatan kualitatif dengan jenis penelitian studi kasus. Lokasi penelitian dilakukan di kampus 4 Universitas PGRI Semarang. informan dalam penelitian ini adalah 23 mahasiswa semester 5 yang mengikuti mata kuliah statistika multivariat, 1 kaprodi pendidikan ekonomi dan 1 dosen pengampu mata kuliah statistika multivariat.

Teknik pengumpulan data yang digunakan adalah teknik observasi yang dilakukan oleh peneliti dengan melihat secara langsung kegiatan pembelajaran mata kuliah multivariat. Teknik dokumentasi digunakan oleh peneliti untuk mendapatkan hasil belajar mata kuliah multivariat, dan teknik pengambilan wawancara dilakukan oleh peneliti kepada dosen dan mahasiswa untuk memperoleh informasi secara mendalam. Penelitian ini menggunakan validitas dan reabilitas data dengan menggunakan triangulasi. Hadi (2017) berpendapat, triangulasi suatu teknik pemeriksaan keabsahan data yang dilakukan untuk pengecekan atau perbandingan data. Triangulasi juga digunakan untuk keperluan pengecekan data dan pembanding data terhadap data yang diperoleh. Triangulasi yang digunakan pada penelitian ini menggunakan triangulasi sumber dan triangulasi teknik.

Penelitian ini menggunakan teknik analisis data interaktif dari (Matthew B. Miles, A. Michael Huberman, 2014) yaitu menganalisis data dengan langkah, kondensasi data yaitu memilah data yang telah diperoleh disesuaikan dengan tujuan penelitian, peneliti menyajikan data dari hasil data yang telah dipilah, dan menarik simpulan atau verifikasi dari data yang telah disajikan sesuai dengan tema penelitian.

\section{HASIL DAN PEMBAHASAN}

Proses Kegiatan Belajar Mengajar Mata Kuliah Statistika Multivariat

Proses pembelajaram mata kuliah Statistika Multivariat yang dilakukan setiap 1 minggu sekali dengan bobot 3 sks sesuai dengan Rencana Perkuliahan Semester (RPS) yang telah dibuat oleh dosen. Perkuliahan tersebut lebih memfokuskan kepada praktik di laboratorium Pendidikan Ekonomi. Praktik penginputan data, output data, dan intepretasi data yang dilakukan menggunakan aplikasi SPSS. 
Penggunaan komputer pada saat melakukan praktik dengan aplikasi SPSS. Mahasiswa diharapkan mampu memahami, menggunakan aplikasi software SPSS, dan menguji statistik inferensial dan jenis uji. Setelah itu, dari hasil pembelajaran tersebut, mahasiswa dapat melakukan perhitungan untuk penelitian skripsi mahasiswa.

\section{Kesesuaian Materi dan Pembelajaran dengan RPS}

Materi dan pembelajaran yang diajarkan oleh dosen sesuai dengan RPS yang dirancang oleh dosen. Mulai dari apa yang diajarkan dosen, metode pembelajaran, dan kriteria penilaian yang ada di RPS sesuai dengan apa yang dosen lakukan disaat proses pembelajaran berlangsung. Hal ini sejalan dengan penelitian yang dilakukan oleh Yamin (2018) yang menyatakan bahwa, RPS dijadikan sebagi dasar dalam melaksanakan pembelajaran. Penggunaan komputer pada pembelajaran Statistika Multivariat untuk melakukan praktik dengan menggunakan aplikasi SPSS. Ketika dosen sudah menjelaskan materi, kemudian dosen memberikan arahan untuk mahasiswa melakukan praktik. Ketika melakukan intepretasi data, dosen membimbing mahasiswa melakukan intepretasi data, karena terdapat beberapa mahasiswa yang kurang memahami bagaimana mengintepretasi data.

\section{Kompetensi Dosen dalam Menumbuhkan Keaktifan Mahasiswa}

Kompetensi dosen untuk dapat menumbuhkan keaktifan mahasiswa sangat diperlukan. Pembelajaran yang baik dapat menumbuhkan minat mahasiswa untuk ikut berpartisipasi dalam pembelajaran. Hal ini sejalan dengan penelitian yang dilakukan oleh Mutmainah (2008), yang menyatakan bahwa seharusnya pembelajaran bisa dipusatkan kepada mahasiswa, sehingga dapat menumbuhkan partisipasi mahasiswa. Pembelajaran Statistika Multivariat yang dilakukan oleh dosen telah memberikan kesempatan kepada mahasiswa untuk bertanya atau menjawab pertanyaan, agar mahasiswa dapat aktif dalam proses pembelajaran. Kesempatan yang diberikan dosen belum dimaksimalkan oleh mahasiswa untuk bertanya atau menjawab pertanyaan.

Keaktifan Mahasiswa dalam Proses Pembelajaran Mata Kuliah Statistika Multivariat

Keaktifan mahasiswa selama proses kegiatan belajar mengajar adalah salah satu indikator adanya motivasi untuk belajar atau ingin tahu. Ketika mahasiswa aktif maka pembelajaran tersebut akan berhasil. Keaktifan mahasiswa saat proses pembelajaran akan menyebabkan interaksi yang tinggi antara mahasiswa dengan dosen sehingga akan terjadi komunikasi yang dua arah. Dari hasil observasi dan wawancara peneliti dengan informan terkait dengan keaktifan, mahasiswa masih jarang untuk bertanya atau menjawab pertanyaan.

Proses pembelajaran pada mata kuliah Statistika Multivariat sudah bagus. Dosen memberikan materi dengan menggunakan Bahasa Inggris selanjutnya mahasiswa diminta mengartikan. Dosen juga memberikan langkah-langkah dalam melakukan input, output, dan intepretasi data. Dosen memberikan arahan saat jalannya praktik. Jika ada mahasiswa yang kesulitan dosen juga membantu. Materi yang diajarkan sudah diupload ke dalam Sistem Informasi Perkuliahan (SIP) Universitas PGRI Semarang sehingga mahasiswa mudah untuk mengaksesnya. Dosen sudah memberikan kemudahan untuk mahasiswanya.

Berdasarkan observasi dan wawancara dengan mahasiswa saat proses pembelajaran berlangsung mahasiswa jarang ada yang bertanya mengenai apa yang sedang diajarkan tetapi lebih bertanya kepada masalah teknis disaat melakukan praktik. Jika mahasiswa kesulitan mereka lebih bertanya kepada teman atau teman yang berada disebelahnya. Tetapi, ada yang langsung bertanya kepada dosen. Jika 
mahasiswa mengalami kesulitan disaat melakukan praktik, mahasiswa akan bertanya kepada teman karena jika tidak bertanya maka akan tertinggal pemahaman dalam tahapan materi perkuliahan.

Dosen mengatakan bahwa dari dulu sampai sekarang ketika mahasiswa praktik komputer jarang atau tidak banyak yang bertanya. Terdapat dua kemungkinan mahasiswa paham atau hanya mengikuti alur saja. Sebagian kecil saja yang betul-betul paham menggunakan komputer. Pertanyaan yang dilontarkan seputar teknis disaat praktik saja. Ketika dosen menjelaskan materinya dan mempersilakan mahasiswa bertanya, tidak ada mahasiswa yang bertanya.

Mahasiswa tidak ada motivasi untuk mencari informasi atau materi yang sudah diajarkan dan yang akan diajarkan. Mahasiswa lebih menerima materi apa saja yang disampaikan oleh dosen atau mengalir begitu saja. Rasa keingintahuan mahasiswa kurang. Sama seperti apa yang diungkapkan mahasiswa yang diwawancarai. Mahasiswa cenderung enggan mencari informasi atau materi untuk memahami secara menyeluruh. Mahasiswa hanya mengikuti pembelajaran dan menerima materi dari dosen saja. Hal ini sejalan dengan penelitian Effendi (2013) ketika proses pembelajaran nampak mahasiswa yang bercanda atau hanya sekedar diam saja.

Tidak ada kemauan dari mahasiswa untuk mencari informasi mahasiswa hanya mengikuti sesuai dengan apa yang diajarkan dosen. Hal itu dapat dilihat dari materi yang diupload oleh dosen, download dan viewnya hanya beberapa saja. Menurut Kaprodi, disaat materi yang sudah diajarkan dari awal sampai yang baru diajarkan, untuk selanjutnya mahasiswa tidak ingin mengetahui. Mahasiswa juga tidak mencari tahu, tidak juga bertanya kepada dosen.

Dosen di kelas berperan sebagai sutradara. Dosen mengatur segalanya yang ada disaat proses pembelajaran berlangsung. Jadi dosen membuat kelas seperti apa tergantung dari dosen tersebut. Ketika kelas tersebut akan dibuat tegang, atau akan dibuat belajar seperti permainan tergantung dari dosen tersebut.

Dampak positif dari keaktifan mahasiswa dalam proses pembelajaran menurut Kaprodi sebagai yaitu dosen menjadi mengetahui seberapa mahasiswa memahami materi yang diberikan. Dosen tidak perlu menjelaskan berulangkali karena dosen telah mengetahui ketika ada pertanyaan dosen sudah paham, bahan apa yang dosen diajarkan, sedangkan mahasiswa belum mengetahui.

Sementara menurut dosen, dampak positifnya adalah mahasiswa tidak akan tertinggal dari berbagai tahapan yang akan dilakukan. Dampak negatif dari kurang aktifnya mahasiswa dalam proses pembelajaran menurut Kaprodi jika mahasiswa tidak aktif, dosen kesulitan untuk mengukur pada saat itu mahasiswa paham atau tidak, jadi membosankan, jadi tidak bersemangat kelasnya. Ketika itu terjadi justru akan menjadi motivasi untuk dosen menjadi semangat mengajar. Menurut dosen ketika mahasiswa tidak mengikuti proses pembelajaran akan tertinggal banyak tahapan yang cukup signifikan.

Dosen melakukan penilaian, berdasarkan upload tugas praktik yang setiap pertemuan dilangsungkan. Mulai dari awal mengikuti praktik di laboratorium Pendidikan Ekonomi kemudian dilihat dari proses prosedur save file mulai dari penginputan data, output data, dan intepretasi data. Mahasiswa mengikuti prosedur save filenya ada yang tertinggal atau tidak. Menilai dari kedisiplinan upload tugas juga menjadi pertimbangan penilaian dari dosen. Selain terampil menggunakan komputer juga terampil menggunakan softwarenya. Jadi keaktifannya dalam hal pengerjaan praktik dan terampil dalam menggunakan software. Ketika proses penilaian praktik yang memang lengkap, sesuai dengan waktunya dalam waktu 
satu hari, dosen akan memberikan poin tersendiri.

Faktor-Faktor yang Mempengaruhi

Melibatkan mahasiswa dalam proses pembelajaran itu sangat diperlukan, karena dalam pembelajaran banyak materi tentang semua pengetahuan yang akan disampaikan yang menuntut keaktifan mahasiswa. Ketika mahasiswa itu aktif maka materi yang akan diterima juga akan lebih luas. Mahasiswa dituntut turut ikut aktif dalam pembelajaran sehingga proses pembelajaran yang terjadi akan lebih interaktif. Interaksi dua arah dari dosen ke mahasiswa atau dari mahasiswa ke mahasiswa sangat membantu dosen dalam mengajar. Hal ini sejalan dengan penelitian yang dilakukan oleh Siagian \& Nurfitriyanti (2015), yang menyatakan bahwa interaksi dua arah antara peserta didik dan pendidik berpengaruh terhadap hasil belajar.

Keaktifan mahasiswa pada saat kegiatan pembelajaran dapat dipengaruhi dari dalam diri mahasiswa itu sendiri atau dari luar mahasiswa. Dari dua faktor tersebut dapat dijabarkan menjadi menjadi beberapa faktor. Kedua faktor tersebut saling berjalan langsung atau tidak langsung sehingga dapat mempengaruhi hasil akhir yang akan didapat oleh mahasiswa. Faktor-faktor tersebut ada yang mendorong mahasiswa untuk aktif dan ada juga yang menghambat mahasiswa untuk ikut aktif dalam kegiatan pembelajaran.

Hasil wawancara dengan informan mahasiswa mengenai faktor yang mendorong mahasiwa ikut aktif jawaban dari mahasiswa tersebut memiliki kesamaan yaitu dari segi mata kuliah yang cukup penting dikarenakan dapat membantu dalam pengerjaan skripsi mereka. Jadi mahasiswa harus mengikutinya, jika tidak mahasiswa akan kebingungan dalam pengerjaan skripsinya. Faktor tersebut yang membuat mahasiswa mengikuti mata kuliah tersebut dengan baik. Faktor lain yang mendorong mahasiswa untuk ikut aktif yaitu dari dosen itu sendiri. Ketika dosen menjelaskan dengan secara runtut dan mudah dipahami mahasiswa akan dengan mudah untuk mengikutinya. Nilai akhir juga dapat mempengaruhi keaktifan mahasiswa.

Sementara faktor yang menghambat menurut mahasiswa itu ada pada sarana dan prasarananya yang masih belum memadai. Masih ada komputer yang tidak berfungsi dan ada yang bisa menyala tetapi aplikasi tidak bisa digunakan. Pengutaraan yang sama juga diutarakan oleh dosen yang terkait mengatakan bahwa komputer yang tersedia masih kurang memadai dan belum ada perbaikan sampai saat ini. Keterbatasan sarana prasarana tersebut membuat mahasiswa harus membawa laptop sendiri jika mereka ingin mengerjakan apa yang diajarkan dan selesai dengan tepat waktu.

Faktor lain yang mendorong mahasiswa untuk ikut aktif dalam proses pembelajaran dari ingin memahami dan mampu menguasai materi. Sementara untuk faktor lain yang menghambat bisa dari benturan dengan kegiatan kampus yang bersifat penting sehingga mahasiswa tidak bisa hadir untuk mengikuti perkuliahan. Menurut Kaprodi Pendidikan Ekonomi berpendapat motivasi mencari ilmu yang ada pada diri mahasiswa dapat menumbuhkan hasrat ingin tahunya itu besar sehingga mahasiswa akan bertanya terus, tetapi di lapangan yang terjadi mahasiswa jarang untuk bertanya.

\section{SIMPULAN DAN SARAN}

Kesimpulan dalam penelitian ini adalah, pembelajaran mata kuliah Statistika Multivariat dilaksanakan dengan baik. Proses kegiatan belajar mengajar mengutamakan keaktifan mahasiswa yang dibuktikan dengan praktik yang dilakukan setiap perkuliahan. Penyampaian materi yang dilakukan menggunakan Bahasa Inggris. Komputer yang ada di laboratorium Pendidikan Ekonomi masih kurang memadai.

Keaktifan mahasiswa masih kurang disebabkan karena mahasiswa tidak memiliki dorongan untuk bertanya. Motivasi mahasiswa untuk ingin tahu masih kurang, karena mahasiswa enggan untuk mencari informasi materi perkuliahan yang sudah diajarkan dan yang akan diajarkan. Agar mahasiwa lebih 
memiliki motivasi belajar maka perlu ada dorongan motivasi dari dosen hingga motivasi dari dalam diri mahasiswa muncul. Penelitian ini memiliki implikasi sebagai sumbangsih kepada dosen agar dapat meningkatkan dorongan dari dalam diri mahasiswa agar dapat meningkatkan keaktifan dalam proses pembelajaran

\section{DAFTAR PUSTAKA}

Akinoǧlu, O., \& Tandoğan, R. Ö. 2007. The effects of problem-based active learning in science education on students' academic achievement, attitude and concept learning. Eurasia Journal of Mathematics, Science and Technology Education, 3(1), 71-81. https://doi.org/10.12973/ejmste/75375

Annisa, M. 2016. Meningkatkan Hasil Belajar Fisika Mahasiswa PGSD Melalui Pembelajaran Berbantuan Internet (E-Learning). Jurnal Lentera Sains, 6(November), 61-67.

Asrori, M. 2016. Pengertian, Tujuan Dan Ruang Lingkup Strategi Pembelajaran. Madrasah, 6(2), 26. https://doi.org/10.18860/jt.v6i2.3301

Daeng, I. T. M., Mewengkang, N. ., \& Kalesaran, edmon R. 2017. Penggunaan Smartphone Dalam Menunjang Aktivitas Perkuliahan Oleh Mahasiswa Fispol Unsrat Manado. E-Journal Acta Diurna, 6(1), $1-15$.

Dolong, H. M. J. 2016. Teknik analisis dalam komponen pembelajaran. Jurnal UIN Alauddin, 5(2), 293-300.

Effendi, M. 2013. Integrasi Pembelajaran Active Learning dan Internet-Based Learning dalam Meningkatkan Keaktifan dan Kreativitas Belajar Mukhlison Effendi. Nadwa: Jurnal Pendidikan Islam, 7.

Fadllan, A. 2010. Strategi Peningkatan Keterampilan Calon Guru dalam Menerapkan Pembelajaran Aktif Melalui MEI (Modelling, Engaging, And Integrating) (Strategy in Improving Prospective Teachers' Skills in Implementing Active Learning through $\mathrm{MEI}$ (Modelling, Engaging, and I. KREATIF Jurnal Kependidikan Dasar, 1(14), 22-32.
Gafar, A. 2008. Penggunaan Internet Sebagai Media Baru dalam Pembelajaran. Jurnal IImiah Universitas Batanghari Jambi, 8(2), 36-43.

Hadi, S. 2017. Pemeriksaan Keabsahan Data Penelitian Kualitatif pada Skripsi. Jurnal IImu Pendidikan, 2122.

Hernawan, A. H., Permasih, H., \& Dewi, L. 2012. Pengembangan bahan ajar. Direktorat UPI, Bandung., 1-13.

Kristiyanti, M. 2010. Internet Sebagai Media Pembelajaran Yang Efektif. Majalah IImiah Informatika, 1.

Larasati, D., Sumastuti, E., Hadi, D., \& Yunus, M. 2020. Pengaruh Media Sosial Dan Status Sosial Ekonomi Terhadap Perilaku Konsumtif Siswa Kelas XI IPS SMA Negeri I Gubug. Oikos: Jurnal Kajian Pendidikan Ekonomi Dan IImu Ekonomi, IV(1), 59-69.

Matthew B. Miles, A. Michael Huberman, J. S. 2014. Qualitative Data Analysis, A Methods Soucebook (3rd ed.). Los Angeles: Sage Publication, Inc.

Mulyani, D. 2013. Hubungan Kesiapan Belajar Siswa dengan Prestasi Belajar. KONSELOR, Jurnal IImiah Konseling, 2(1), 27-31.

Mumtaz, S. 2000. Factors affecting teachers' use of information and communications technology: A review of the literature. Journal of Information Technology for Teacher Education, 9(3), 319-342. https://doi.org/10.1080/14759390000 200096

Mutmainah, S. 2008. Pengaruh Penerapan Metode Pembelajaran Kooperatif Berbasis Kasus yang Berpusat Pada Mahasiswa terhadap Efektivitas Pembelajaran Akuntansi Keperilakuan. Eprints.Undip.Ac.Id.

Ngadiyono, Y. 2009. Pengaruh Strategi Pengulangan Terhadap Kemampuan Retensi Belajar Pneumatik Mahasiswa Pendidikan Teknik Mesin UNY. Jurnal Pendidikan Teknologi Dan Kejuruan, 18(1), 129-149. https://doi.org/10.21831/jptk.v18i1.76 84

Nudji DA. 2014. Upaya Meningkatkan 
Kemandirian Belajar Mahasiswa PPKN Melalui Pembelajaran Lesson Study. Jurnal Heritage, 2(2), 9-18.

Nurseto, T. 2012. Membuat Media Pembelajaran yang Menarik. Jurnal Ekonomi Dan Pendidikan, 8(1), 1935.

https://doi.org/10.21831/jep.v8i1.706

Pane, A., \& Darwis Dasopang, M. 2017. Belajar Dan Pembelajaran. FITRAH:Jurnal Kajian IImu-IImu Keislaman, 3(2), 333. https://doi.org/10.24952/fitrah.v3i2.94 5

Pujiningsih Sri dan Mustikawati Indah. 2004. Kemandirian Belajar dalam Meningkatkan Prestasi Mahasiswa Pendidikan Akuntansi. Jurnal Pendidikan Akuntansi Indonesia, III(1), 12-18.

Riwayadi, P. 2013. Pemanfaatan Perkembangan Teknologi Informasi Dan Komunikasi Untuk Kemajuan Pendidikan di Indonesia. Prosiding The 5th International Conference on Indonesian Studies: "Ethnicity and Globalization," 362-371.

Shadiq, F. 2009. Psikologi Pembelajaran Matematika. In Pusat Pengembangan dan Pemberdayaan Pendidik dan Tenaga Kependidikan Matematika. https://doi.org/10.1371/journal.pone.0 045739

Siagian, R. E. F., \& Nurfitriyanti, M. 2015. Metode Pembelajaran Inquiry dan Pengaruhnya Terhadap Hasil Belajar Matematika ditinjau dari Kreativitas Belajar. Formatif: Jurnal IImiah Pendidikan MIPA, 2(1), 35-44.

Tatang Hidayat, M. S. 2019. Filsafat Perencanaan dan Implikasinya dalam Perencanaan Pembelajaran Pendidikan Agama Islam di Sekolah. Lentera Pendidikan: Jurnal IImu Tarbiyah Dan Keguruan, 21(2), 188205.

Widoyoko, E. P. 2009. Evaluasi Program Pembelajaran. Pustaka Pelajar, 5(1), $1-16$. https://doi.org/10.21831/cp.v5i1.1266

Yamin, M. M. 2018. Validitas Rencana Pembelajaran Semester Mata Kuliah Kimia Dasar Program Studi Pendidikan Biologi Universitas. Jurnal
Eksakta Pendidikan, 2, 49-55.

Yunus, M. 2013. Pengaruh Pemberian Motivasi Belajar oleh Guru Terhadap Prestasi Belajar Siswa pada Mata Pelajaran IPS di SMP NU 01 Hasyim Asy'ari Tarub Tahun Pelajaran 20122013. OSF.Io. 